\title{
Redistribution of spat-sized Macoma balthica in the Wadden Sea in cold and mild winters
}

\author{
J. J. Beukema*, R. Dekker \\ Royal Netherlands Institute for Sea Research, PO Box 59, Den Burg, Texel, The Netherlands
}

\begin{abstract}
During the first winter of their life, large numbers of the tellinid bivalve Macoma balthica (L.) migrate from their first-summer coastal nurseries on high tidal flats in the Wadden Sea to areas further offshore, including low tidal flats and subtidal areas in the Wadden Sea and adjacent parts of the North Sea. In the western part of the Dutch Wadden Sea, we compared M. balthica redistribution in cold and mild winters during the 29 years from 1973 to 2002 to find out whether migration activity was related to winter character. Migration occurred on a larger scale in cold winters than in mild winters, with larger decreases in density of coastal populations and larger increases in density of offshore populations following a cold winter than following a mild winter. In subtidal areas, such secondary recruitment, at an age of almost $1 \mathrm{yr}$, was higher than primary recruitment through post-larval settlement. In subtidal areas, $M$. balthica year-classes were particularly strong when their first winter had been cold and when primary first-summer recruitment had been abundant in nearby coastal tidal-flat areas.
\end{abstract}

KEY WORDS: Migration $\cdot$ Secondary recruitment $\cdot$ Winter temperature $\cdot$ Macoma balthica $\cdot$ Wadden Sea $\cdot$ North Sea

Resale or republication not permitted without written consent of the publisher

\section{INTRODUCTION}

During their first summer and autumn, postlarval (spat) stages of the tellinid bivalve Macoma balthica (L.) are particularly numerous on tidal flats in the upper half of the intertidal zone. A high proportion of these spat-sized $(\sim 0.5 \mathrm{~cm}$ shell length) bivalves migrate during their first winter, leaving their coastal nurseries to move to lower intertidal and subtidal levels (Beukema 1973, 1993, Beukema et al. 1978) by pelagic thread-drifting (Sörlin 1988, Beukema \& De Vlas 1989). Sörlin (1988) observed that low temperatures stimulate floating behaviour, and Hiddink \& Wolff (2002) found that the colder the water in winter and early spring, the more drifting $M$. balthica spat were caught by plankton nets. Thus, winter migration of this species may be more intense on colder than on milder days. Because Hiddink \& Wolff (2002) measured abundance over a short period only, they could not assess whether spat migration had indeed been more effective during cold than mild winters.
In the Wadden Sea area, the number of cold days differs widely from winter to winter. In the mildest winters, no days with maximum air temperatures below $0^{\circ} \mathrm{C}$ are recorded, whereas in cold winters many such days occur. The observations of Hiddink \& Wolff (2002) suggest that more Macoma balthica spat would migrate from high/coastal tidal flats to low/offshore areas in cold than in mild winters.

Long-term annual data on the density of Macoma balthica of known age for 15 intertidal sites and 3 subtidal sites in the western part of the Wadden Sea, and for 1 subtidal site in the North Sea, enabled 3 hypotheses to be tested: (1) the decline of spat densities in high/coastal tidal flats is larger in cold than in mild winters; (2) there is a higher increase (or a lower decrease) in spat densities in low/offshore areas in cold than in mild winters; (3) in subtidal areas, year-classes that experienced a cold winter during the first year of their life are generally stronger than those that experienced a mild winter during their first year. 


\section{MATERIALS AND METHODS}

Most data on Macoma balthica densities (ind. $\mathrm{m}^{-2}$ ) were obtained from a long-term monitoring programme of the macrobenthic fauna of Balgzand, a $50 \mathrm{~km}^{2}$ tidal flat area in the westernmost part of the Wadden Sea $\left(52^{\circ} 54^{\prime} \mathrm{N}, 4^{\circ} 48^{\prime} \mathrm{E}\right)$ (Fig. 1a). This programme includes bi-annual quantitative sampling at 15 sites, with a $1 \mathrm{~mm}$ sieve. The present study examined the density of 0 - and I-group $M$. balthica in late summer (mostly August) which has been consistently assessed since 1973 (0-group or spat are <1 yr old, I-group animals are between 1 and 2 yr old). Thus, a homogeneous series of 29 estimates of annual (August to August) changes in density of juvenile $M$. balthica are available for the Balgzand area. The 15 sampling sites are scattered throughout Balgzand (Fig. 1b), at distances of between 0 and $9 \mathrm{~km}$ from the SW coast. Along this coast, a $\sim 1 \mathrm{~km}$ wide area lies well above mean tidal level (MTL) and constitutes a typical nursery area for $M$. balthica spat, which are present at high densities during their first summer (Beukema 1993).

The 15 sampling sites on Balgzand cover the entire intertidal zone from about $+0.5 \mathrm{~m}$ to about $-1.0 \mathrm{~m}$ relative to MTL. The sites were divided into 3 groups of 5 sites each, viz. a high/coastal group $(<1.5 \mathrm{~km}$ from the SW coast and mainly at or above MTL), a low/offshore group ( $>6 \mathrm{~km}$ from the SW coast and mainly $>0.5 \mathrm{~m}$ below MTL), and an intermediate group (2 to $5 \mathrm{~km}$ from the SW coast and mainly around $0.5 \mathrm{~m}$ below MTL). (See Fig. 3 of Beukema 1993 for details on the intertidal levels of the various sampling sites.)

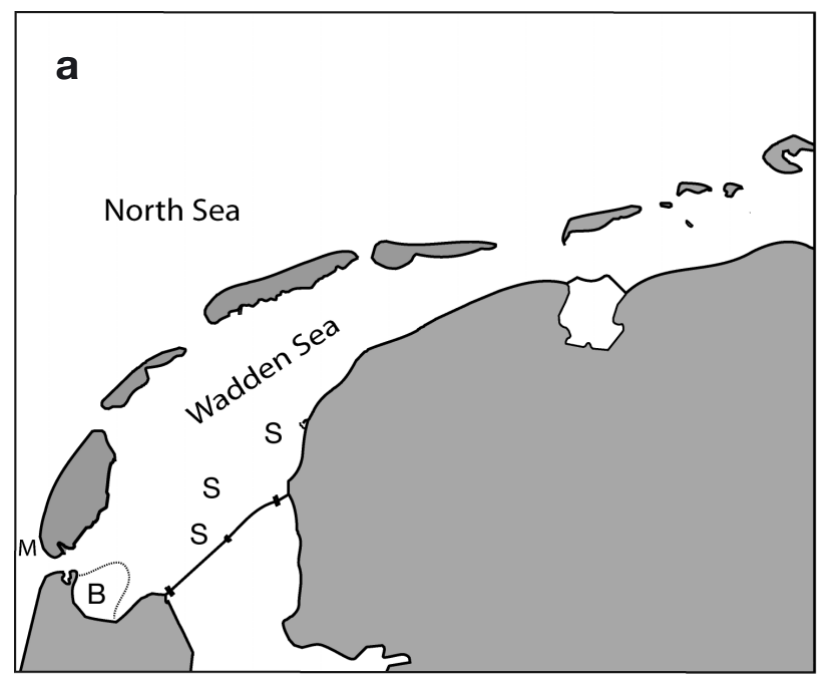

In the subtidal area, the population dynamics of 0 and I-group Macoma balthica populations were studied from 2 data sets: (1) macrozoobenthos samples taken in August and September during 1989 to 2002 along 3 subtidal transects (20 to $50 \mathrm{~km} \mathrm{NE}$ of Balgzand and at distances of 10 to $20 \mathrm{~km}$ [mean $\sim 17 \mathrm{~km}$ ] from high coastal tidal flats; cf. Dekker \& De Bruin 2001) at a depth of 1.5 to $5 \mathrm{~m}$ below MTL, (2) macrozoobenthos samples taken in late spring during 1971 to 1982 in a shallow area $(\sim 6 \mathrm{~m})$ of the Molengat (North Sea off Texel, see Fig. 1a).

Temperature records were obtained from monthly weather reports (issued by the Royal Dutch Meteorological Institute, KNMI) for the weather station 'De Kooy' located $1 \mathrm{~km}$ from Balgzand. During the 29 winters of the 1973 to 2002 period, the number of cold days (maximum temperature $<0^{\circ} \mathrm{C}$ ) varied between 0 and 39 with an average of $9 \mathrm{~d}$ and displayed a highly skewed distribution with only a quarter of the winters accounting for two-thirds of the number of cold days. The 7 coldest winters contributed at least 15 cold days each (average $24 \mathrm{~d}$ ). The remaining 22 winters with 11 or fewer cold days had, on average, only 4 cold days. Because of the shallowness of the Wadden Sea, water temperatures closely follow air temperatures, resulting in a strong similarity in the designation of winters as cold or mild regardless of whether air or water temperatures were used as criterion.

In the Wadden Sea area, cold winters are further characterised by prevailing easterly winds and high air pressure, causing, on average, lower tides in cold than in mild winters (e.g. Anonymous 1994). As a consequence, water exchange between the North Sea and the Wadden Sea is slightly less in cold winters, and

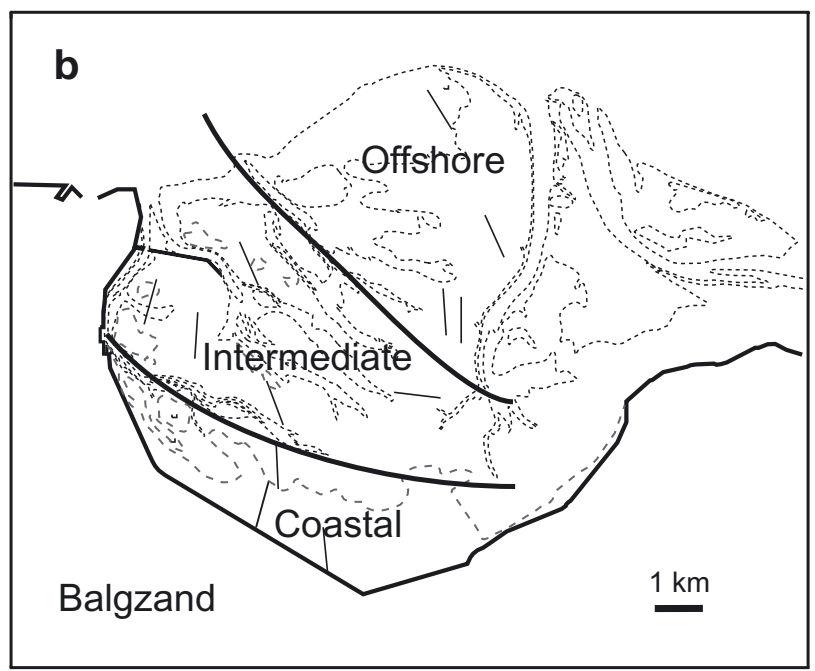

Fig. 1. (a) Dutch Wadden Sea, showing positions of sampling sites. M: Molengat; S: 3 subtidal transects in the Wadden Sea. (b) Intertidal area 'Balgzand' (B), showing position of 12 transects of $1 \mathrm{~km}$ (straight lines) and 3 areas of $1000 \mathrm{~m}^{2}$ each. The thick continuous lines separate 3 parts of Balgzand (offshore, intermediate, and coastal), which contain 5 sampling sites each 
mean current speeds are lower in cold than in mild winters. High wind-speeds occur less frequently in cold than in mild winters.

We studied changes in the numerical density of Macoma balthica between the first and second latesummer (hereafter 'August') of life. The age of juvenile individuals was easily assessed from the number of year marks on their shells (see Lammens 1967). We compared data for $7 \mathrm{yr}$ including a cold winter $(>14$ cold days) with data for $7 \mathrm{yr}$ with no cold winter $(<12$ cold days). For each of the 15 individual sampling sites on Balgzand, the latter 7 yr were chosen from the 22 non-cold years of the 1973 to 2002 period on the base of similarity in initial (Age-0) $M$. balthica densities. To enable a paired comparison, the density preceding a mild winter should not deviate by more than $50 \%$ from the density preceding the cold winter. At each site, a mild-winter data set was used only once for a comparison. This matching procedure was followed because proportional declines tend to be stronger at high than at low initial densities (see Van der Meer et al. 2001) and initial-density matching thus enhances the precision of comparisons. In the intertidal area, 7 comparisons (less if no satisfactory match was available or no $M$. balthica were found at both sampling occasions) were made at each site, yielding 31 to 35 comparisons per group of 5 sites. In the subtidal Wadden Sea area, the much shorter sampling period (13 yr as compared to $29 \mathrm{yr}$ in the intertidal area) contained only 2 cold winters and the number of comparisons was, therefore, limited to 6 (2 year-pairs at each of 3 sites).

\section{RESULTS}

\section{Differential migration in cold and mild winters}

At nearly all intertidal stations, numerical density of juvenile Macoma balthica declined during the first year of their life in nearly all years. Particularly strong annual declines (to only about $10 \%$ of their initial numbers) were observed at some high-tidal coastal sites, whereas declines were generally less marked at sites further from the coast and at lower elevations (Fig. $2 \mathrm{a}, \mathrm{b}$ ). Such trends with distance (shown as best linear fits in Fig. 2) were statistically significant for both the year-group with cold and the year-group with mild winters (Spearman's rank-correlation tests; $\mathrm{n}=16$, $\mathrm{p}<0.001$ for cold winters and $\mathrm{p}<0.05$ for mild winters). At sites $>8 \mathrm{~km}$ from the coast, mean increases rather than decreases were observed (see positive values for some offshore sites in Fig. 2). In these offshore areas, immigration was apparently higher than mortality and emigration.
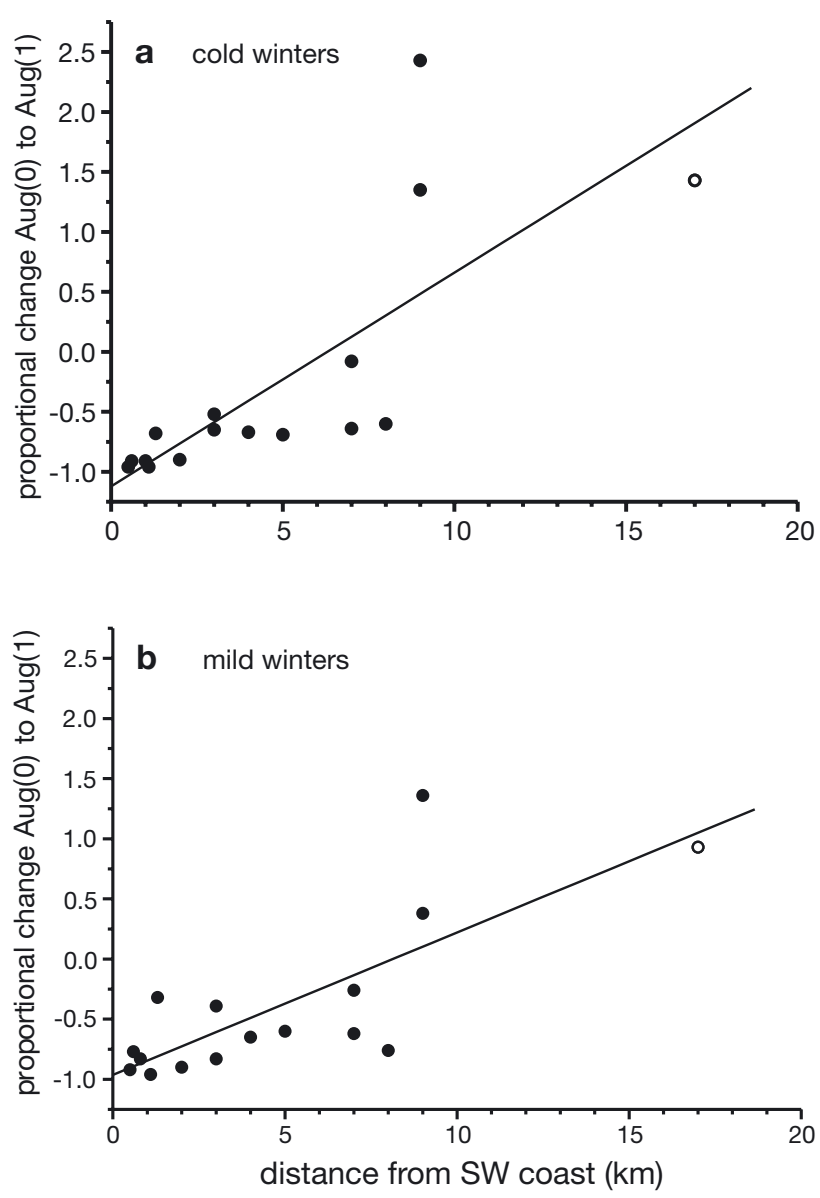

Fig. 2. Macoma balthica. Average change in number of juveniles observed between first estimate in August at Age 0 and 1 yr later, expressed as a proportion (p) of the number at the first estimate. One point $(\bullet)$ is shown for each of 15 intertidal sampling sites and 1 additional point (o) for the 3 subtidal Wadden Sea sites combined. Intertidal sites arranged in order of increasing distance $(\mathrm{d}, \mathrm{km})$ from SW coast of Balgzand; subtidal site is $17 \mathrm{~km}$ (mean of 3 distances) from nearby high tidal flat area. (a) Following cold winters ( $>15$ d with temperatures $<0^{\circ} \mathrm{C}$ ); (b) following mild winters (selected winters with $<11$ similarly cold days and with similar spat abundance before onset of winter). Data are weighted averages (ind. $\mathrm{m}^{-2}$ ) of 1 yr olds in 7 different years, divided by total number of individuals of the same year-class present $1 \mathrm{yr}$ earlier at the same site. Linear fits: (a) $\mathrm{p}=-1.12+0.18 \mathrm{~d}, \mathrm{n}=16, \mathrm{R}^{2}=0.57$, $\mathrm{p}<0.001$; (b) $\mathrm{p}=-0.96+0.12 \mathrm{~d}, \mathrm{n}=16, \mathrm{R}^{2}=0.58, \mathrm{p}<0.001$

Were offshore winter migration more substantial in cold than in mild winters, the slope of the linear fits shown in Fig. 2 would be steeper in years including a cold winter than in mild-winter years. Although this appears to be the case, the difference in slope $(0.178$ for cold winters minus 0.118 for mild winters) is 0.060 ( $\mathrm{SE}=$ $0.31)$ i.e. statistically barely significant $(p=0.04,1$-sided test). Therefore, we rearranged the data, grouping data from individual sampling sites with similar distances from the coast, and compared paired values. 
The group of 5 coastal sites yielded 35 pairs of annual changes after either a cold or a mild winter. In the majority of comparisons (25 cases), the decline in density was stronger after a colder winter (statistically significant: ranked-sign test, $\mathrm{p}<0.01, \mathrm{n}=35$ ). In contrast, at the 5 offshore sites (yielding 30 differences of proportional changes) stronger decreases (or weaker increases) after cold than after mild winters occurred in a minority of cases ( 10 times: $p<0.05$, ranked-sign test, $n=30$ ). In the intermediate area, no significant difference between years with cold and mild winters was observed (stronger population declines after cold winters occurred in 15 of 33 cases). Thus, following cold winters, large decreases were significantly more frequent in coastal areas, whereas smaller decreases or larger increases were recorded more frequently in offshore areas.

To reveal possible differences in the mean magnitude of these changes, average ( 5 sites, $7 \mathrm{yr}$ ) changes were calculated together with their standard errors. In coastal and intermediate areas, mean decreases occurred (Fig. 3). In the high-tidal coastal area, these decreases were significantly higher (82 vs 72\%) in years including a cold winter $(\mathrm{p}<0.01$, Student's $t$-test, $\mathrm{n}=35$ ). In the intertidal area offshore and the subtidal area, even further offshore, mean increases occurred (Fig. 3). Density increases in the intertidal offshore area were significantly higher following cold than following mild winters $(\mathrm{p}<0.01$, Student's $t$-test, $\mathrm{n}=31$ ).

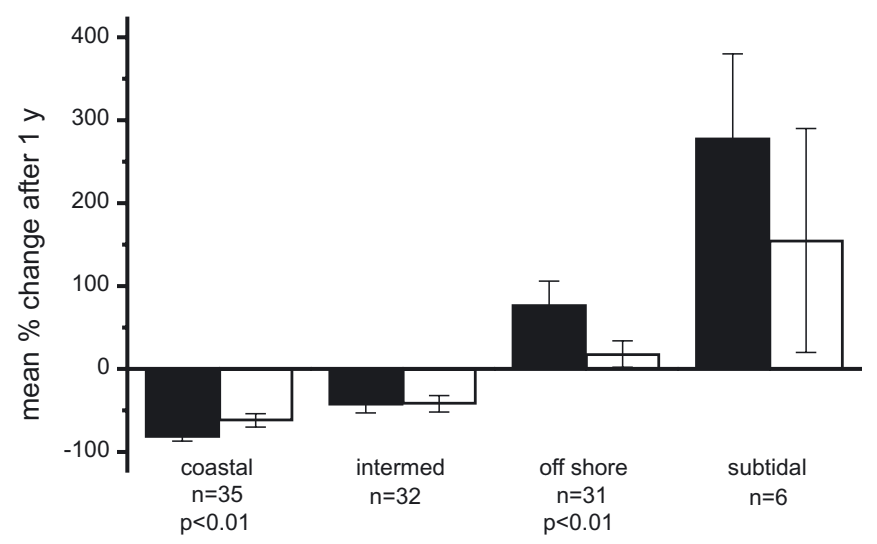

Fig. 3. Macoma balthica. Mean $( \pm \mathrm{SE})$ relative changes in numerical density of juveniles in 4 Wadden Sea areas between the first and second August of life (percent of ind. $\mathrm{m}^{-2}$ present at first sampling). Data are from 31 to 35 observations (usually) of 2 groups of $7 \mathrm{yr}$, one including a cold winter (black columns) and the other including a mild winter (white columns); subtidal columns comprised 6 data (2 yr and 3 sites, ' $\mathrm{S}$ ' in Fig. 1a). Columns are arranged in order of increasing distance from the SW coast of Balgzand, i.e. coastal, intermediate, offshore (cf. Fig. 1b). Subtidal sites were more distant from high tidal-flat areas than offshore intertidal stations. For both coastal and offshore groups, differences between cold and mild winters were statistically significant $(\mathrm{p}<0.01$, Student's $t$-test ; coast: $\mathrm{n}=70$, offshore: $\mathrm{n}=62$ )
In the subtidal offshore area, the mean increases were statistically non-significant, although the values (and their difference) were even greater than in the offshore intertidal (Fig. 3); however, the number of observations was low $(\mathrm{n}=6)$.

Comparison of Fig. 3 with Fig. 2 confirms that the suggested (although statistically barely significantly) steeper trend of density change in years with a cold winter (Fig. 2a vs Fig. 2b) arose from a statistically significant stronger decline in Macoma balthica abundance near the coast and a stronger increase in offshore areas (including subtidal parts of the Wadden Sea).

\section{Winter temperatures and Macoma balthica year-class strength in subtidal areas}

In subtidal parts of the Wadden Sea and nearby parts of the North Sea, density of Macoma balthica spat during their first summer is usually 1 or 2 orders of magnitude lower than spat density simultaneously observed on intertidal flats of the Wadden Sea. For instance, at the 3 subtidal Wadden Sea sampling sites, the 14-yr mean density of 0 -group animals was $10( \pm 2, \mathrm{SE}) \mathrm{m}^{-2}$, whereas it was $203 \pm 84 \mathrm{~m}^{-2}$ in the intertidal of Balgzand during the same period. Even lower preimmigration spat densities were observed in the North Sea off Terschelling (Beukema \& De Vlas 1989). At an age of $1 \mathrm{yr}$, densities in subtidal areas were generally much higher than densities 1 yr previously (>100\% values in right-hand bars of Fig. 3 for subtidal Wadden Sea; see also table 1 of Beukema \& De Vlas 1989 for North Sea). Most M. balthica in all these subtidal areas must thus have been immigrants from other areas that undertook winter migrations at 0.5 to $1 \mathrm{yr}$ of age. Therefore, winter temperatures are presumed to play a role in the establishment of year-class strength of M. balthica in these subtidal areas.

As the number of 1-yr-olds in immigration areas is expected to depend also on the number of 0 -group Macoma balthica available at the start of the migration season, in the areas of primary (post-larval) recruitment we evaluated the data by an analysis of variance, using both a quantitative index of winter characteristic (i.e. number of cold days) and an index of 0-group abundance (i.e. ind. $\mathrm{m}^{-2}$ in late summer in the hightidal coastal parts of Balgzand) as covariates, with area as a category (i.e. North Sea and Wadden Sea, since data from these 2 subtidal sampling areas were combined). All numbers were log-transformed to homogenise variances.

The results of the ANOVA (Table 1) revealed that the I-group numbers in the subtidal immigration areas differed significantly between the 2 areas $(p<0.01)$, between winters with different characteristics $(p=0.05)$, as well as between years differing in 
Table 1. Results of 3-factor ANOVA of area (10 observations in Molengat area in North Sea 1971 to 1983, and 14 in subtidal parts of western Wadden Sea 1988 to 2002), winter characteristic (log number of cold days), and 0-group abundance (Macoma balthica spat density on high coastal tidal flats in preceding summer, log ind. $\mathrm{m}^{-2}$ ) on log-transformed numerical densities of $\sim 1$-yr juveniles observed in areas with little primary 0-group recruitment. Squared multiple $r=0.46$

\begin{tabular}{|lccccc|}
\hline $\begin{array}{l}\text { Source of } \\
\text { variation }\end{array}$ & df & SS & MS & $\begin{array}{c}\text { Estimated } \\
\text { F-ratio }\end{array}$ & $\mathrm{p}$ \\
\hline Area & 1 & 4.24 & 4.24 & 10.76 & 0.004 \\
$\begin{array}{l}\text { Winter } \\
\text { characteristic }\end{array}$ & 1 & 1.72 & 1.72 & 4.36 & 0.050 \\
$\begin{array}{l}\text { 0-group } \\
\text { abundance }\end{array}$ & 1 & 2.37 & 2.37 & 6.03 & 0.023 \\
Error & 20 & 7.88 & 0.39 & & \\
\hline
\end{tabular}

0 -group abundance in the summer nurseries $(\mathrm{p}<0.05)$. Low densities (generally $<10 \mathrm{~m}^{-2}$ ) of 1 -yr-olds in the subtidal areas were found following milder winters and also when 0 -group densities in the preceding summer had been relatively low in the summer nurseries, whereas higher densities (generally tens $\mathrm{m}^{-2}$ ) were found following colder winters or $1 \mathrm{yr}$ after spat densities had been high in the coastal nurseries.

\section{DISCUSSION}

\section{Migration}

At any sampling site, changes in numbers after initial recruitment occur through mortality, migration or (as in the case of the highly mobile spat of Macoma balthica) both. High mortality rates combined with emigration result in high decreases in density, whereas high immigration rates mitigate such decreases and may even result in increased density. We believe that the interplay of these processes underlies the pattern of changing abundance of juvenile $M$. balthica with increasing distance from the coast (see Figs. 2 \& 3); i.e. mortality + emigration characterising first-summer nurseries close to the coast, balanced mortality and immigration intermediately offshore areas, and immigration exceeding mortality in areas furthest from the coast (including the subtidal Wadden Sea and North Sea). Migration appears to be more substantial in years with a cold winter. It is not known whether mortality in juvenile $M$. balthica differs between cold and mild winters (although $M$. balthica as a species does not suffer higher mortality rates in cold winters than in mild winters; see Beukema 1990). However, the fact that more individuals migrate to offshore areas in cold than in mild winters, means that more have emigrated from other areas. As coastal areas are the only rich source area for such emigrants, the larger declines in density observed in coastal areas in years with colder winters probably arose from enhanced emigration.

Not all spat migrating to the subtidal areas in our study are presumed to have originated from Balgzand coastal flats. However, since parallel fluctuations in summer recruitment (initial year-class strength) occur in various intertidal areas of the Wadden Sea (Beukema et al. 2001), possible differences in origin do not invalidate our conclusions.

The higher numbers of pelagic juvenile Macoma balthica observed at low (around freezing) than at high $\left(>5^{\circ} \mathrm{C}\right)$ water temperatures by Hiddink \& Wolff (2002) do indeed indicate increased migration on cold days. Since these authors carried out their observations in a period of mild winters, their estimates of the proportions of juvenile $M$. balthica emigrating from high to lower areas may be underestimates when viewed in the long-term. In cold winters, migration may be even more substantial than suggested by their data.

We found evidence for all 3 hypotheses formulated (see 'Introduction') and conclude that the higher concentrations of thread-drifting Macoma balthica spat on cold than on mild winter days observed by Hiddink \& Wolff (2002) indicate a more intensive migration in cold than in mild winters, as supported by (1) greater decreases in spat numbers in coastal areas, (2) greater increases in both offshore and subtidal areas, and (3) significantly denser stocks in such areas following cold than following mild winters.

\section{Causal aspects}

The higher concentrations of thread-drifting Macoma balthica observed by Hiddink \& Wolff (2002) in winter on days with colder water could arise from 2 phenomena: (1) Spat-sized M. balthica are stimulated to leave their buried position in the sediment by low temperatures (Sörlin 1988), and/or (2) sinking rates are lower at low water temperatures due to higher water viscosity (Spaargaren 1980). The relative importance of differential sinking rates has not been assessed. Active entry into the water column appears to be important. Passive resuspension will generally be less intense in cold than in mild winters as high speeds of wind and current are less frequent in cold than mild winters.

\section{Functional aspects}

Although migration involves serious risks (Hiddink 2002, Hiddink \& Wolff 2002, Hiddink et al. 2002), Macoma balthica that move successfully from high 
tidal coastal nurseries to deeper offshore areas may have increased chances of survival (cf. Fig. 7 and Table 1 of Beukema 1993), more rapid growth (cf. Fig. 8 and Table 1 of Beukema 1993), and a higher reproductive output (Table 1 of Beukema 1993, see also Van der Meer et al. 2003) in offshore adult populations (see also Hiddink 2002).

Is it more favourable to migrate during a cold than during a mild winter? The following might apply:

(1) As a consequence of lower sinking rates caused by higher viscosity, horizontal displacements may cover longer distances in cold than in mild winters, and thus migration may be more effective in cold winters. In particular, the migration offshore may be reinforced, as water tends to be colder during ebb than during flood tides in winter (Postma 1983).

(2) The mortality risks during migration (and when leaving or entering the upper sediment layer) may be mitigated by low temperatures, since at low temperatures (mostly cold-blooded) predators are less active and perhaps also less numerous (e.g. in cold winters shore crabs and shrimps move further offshore than in mild winters: Klein Breteler 1976, Boddeke 1976, respectively).

(3) In coastal areas, low temperatures may aggravate mortality due to adverse environmental conditions more than in offshore areas. We do not support the (unfounded) statement by Günther (1992) that winter migrations from tidal to subtidal areas are obviously performed to avoid getting frozen, because Macoma balthica is not among the winter-sensitive Wadden Sea species (Beukema 1990). In adult (non-migratory) $M$. balthica, the total Balgzand death rates were lower in years including a cold winter than in years including a mild winter (J. J. Beukema unpubl. obs.). However, in the highest areas (well above MTL), the reverse was true. In these coastal areas, rather than low temperature, prolonged emersion times caused by lowered water levels due to prevailing easterly winds and high atmospheric pressure may have been an additional cause of mortality in severe winters.

Acknowledgements. This study is part of a long-term monitoring programme on macrozoobenthos in the Wadden Sea financially supported by the National Institute for Coastal and Marine Management (RWS/RIKZ).

\section{LITERATURE CITED}

Anonymous (1994) Tienjarig overzicht (presentatie van afvoeren, waterstanden, watertemperaturen, golven en kustmetingen). Ministerie Verkeer en Waterstaat, The Hague Beukema JJ (1973) Migration and secondary spatfall of

Editorial responsibility: Otto Kinne (Editor),

Oldendorf/Luhe, Germany
Macoma balthica (L.) in the western part of the Wadden Sea. Neth J Zool 23:356-357

Beukema JJ (1990) Expected effects of changes in winter temperatures on benthic animals living in soft sediments in coastal North Sea areas. In: Beukema JJ, Wolff WJ, Brouns JJWM (eds) Expected effects of climatic change on marine coastal ecosystems. Kluwer Academic Publishers, Dordrecht, p 83-92

Beukema JJ (1993) Successive changes in distribution patterns as an adaptive strategy in the bivalve Macoma balthica (L.) in the Wadden Sea. Helgol Meeresunters 47: $287-304$

Beukema JJ, De Vlas J (1989) Tidal-current transport of thread-drifting postlarval juveniles of the bivalve Macoma balthica from the Wadden Sea to the North Sea. Mar Ecol Prog Ser 52:193-200

Beukema JJ, De Bruin W, Jansen JJM (1978) Biomass and species richness of the macrobenthic animals living on the tidal flats of the Dutch Wadden Sea: long-term changes during a period with mild winters. Neth J Sea Res 12:58-77

Beukema JJ, Dekker R, Essink K, Michaelis H (2001) Synchronized reproductive success of the main bivalve species in the Wadden Sea: causes and consequences. Mar Ecol Prog Ser 211:143-155

Boddeke R (1976) The seasonal migration of the brown shrimp Crangon crangon. Neth J Sea Res 10:103-130

Dekker R, De Bruin W (2001) Het macrozoobenthos op twaalf raaien in de Waddenzee en de Eems-Dollard in 2000. NIOZ-Rapport 2001-1, Netherlands Institute for Sea Research, Texel, p 1-59

Günther CP (1992) Dispersal of intertidal invertebrates: a strategy to react to disturbances of different scales? Neth J Sea Res 30:45-56

Hiddink JG (2002) The adaptive value of migrations for the bivalve Macoma balthica. PhD thesis, State University of Groningen, Groningen

Hiddink JG, Wolff WJ (2002) Changes in distribution and decrease in numbers during migration of the bivalve Macoma balthica. Mar Ecol Prog Ser 233:117-130

Hiddink JG, Kock RP, Wolff WJ (2002) Active pelagic migrations of the bivalve Macoma balthica are dangerous. Mar Biol 140:1149-1156

Klein Breteler WCM (1976) Migration of the shore crab, Carcinus maenas, in the Dutch Wadden Sea. Neth J Sea Res 10:338-353

Lammens JJ (1967) Growth and reproduction in a tidal flat population of Macoma balthica (L.). Neth J Sea Res 3: 315-382

Postma H (1983) Hydrography of the Wadden Sea: movements and properties of water and particulate matter. In: Wolff WJ (ed) Ecology of the Wadden Sea, Vol 1, Rep 2, Balkema, Rotterdam, p 1-75

Sörlin T (1988) Floating behaviour in the tellinid bivalve Macoma balthica (L.). Oecologia 77:273-277

Spaargaren DH (1980) The significance of seawater viscosity for the tidal transport of common shrimps, Crangon crangon (L.). Ophelia 19:145-153

Van der Meer J, Beukema JJ, Dekker R (2001) Long-term variability in secondary production of an intertidal bivalve population is primarily a matter of recruitment variability. J Anim Ecol 70:159-169

Van der Meer J, Beukema JJ, Dekker R (2003) Large spatial variability in lifetime egg production in an intertidal Baltic tellin (Macoma balthica) population. Helgol Mar Res 56: $274-278$

Submitted: April 19, 2003; Accepted: September 16, 2003

Proofs received from author(s): December 16, 2003 